\title{
Regrowth and rest requirements of northern wheatgrass following defoliation
}

\author{
BRENDAN L. KOWALENKO AND J.T. ROMO
}

Authors are former graduate student and professor, Dept. of Crop Sci. and Plant Ecology, Univ. of Saskatchewan, Saskatoon, SK S7N SA8, Canada. JTR is corresponding author.

\begin{abstract}
Degree-days required for standing crop and above-ground net primary production of northern wheatgrass (Agropyron dasystachyum [Hook.] Scribn., syn. Elymus lanceolatus [Scrib. \& Smith] Gould) mowed to a 5-cm stubble to recover to levels similar to an unmowed control were determined in southwestern Saskatchewan. Nine, single mowing treatments and an unmowed control were established from early May through late August in 1991 and 1992 on a clayey range site at 2 locations. Green and dead phytomass and above-ground net primary production were determined for 2 to 3 years following mowing. Degree-days required for recovery of green and dead standing phytomass on mowed plots decreased linearly and were highly correlated $\left(r^{2}=\right.$ 0.64 to 0.99 ) with the number of days plots were mowed after 1 May. Regardless of mowing date, green phytomass did not recover to control levels the year of mowing. Each day mowing was delayed past 1 May reduced the number of degree-days required for total recovery of green phytomass on mowed plots by 15.7 in 1991 and 17.7 in 1992 . Degree-days required for recovery of standing dead on mowed plots were reduced 17.6 in 1991 and 15.8 in 1992. Degree-days required for recovery of above-ground net primary production declined linearly $\left(r^{2}=0.67\right.$ and 0.99$)$ as mowing was delayed after 1 May. More degree-days were required for the 1991 than 1992 plots. At least 2 and sometimes 3 growing seasons were required to accumulate enough degreedays to allow full recovery of green and standing dead phytomass and above-ground net primary production on mowed plots. For optimum sustained production, a grazing system should be used on northern wheatgrass-dominated rangeland with a 2 year rest period applied to paddocks after grazing.
\end{abstract}

Key words: above-ground net primary production, Agropyron dasystachyum (Hook.) Scribn., degree-days, Elymus lancevlatus (Scrib. \& Smith) Gould, grazing management, growing degreedays, Northern Mixed Prairie, regrowth

Preventing over-grazing is central to all grazing management plans. Overly frequent or improperly timed grazing reduces vigor and abundance of grasses (Holscher 1945, Zhang and Romo

This research was funded by the Saskatchewan Agriculture-Agriculture Development Fund and the Natural Sciences and Engineering Research Council. Appreciation is extended to Drs. M.R. Haferkamp and W.D. Willms for constructive comments on earlier versions.

Manuscript accepted 25 Jan. 1997.
1994). Over-grazing occurs when plants are regrazed before they have recovered from the previous defoliations. Thus, preventing over-grazing requires that plants receive rest after grazing (Voisin 1959).

Length of rest required for plants to recover from grazing varies from days to years (Voisin 1959, Mueggler 1975, Trlica et al. 1977). Plants generally respond to rest more quickly in mesic than in xeric areas, and on high versus poorer condition ranges (Anderson and Holte 1981).

Mixed prairie species, defoliated more than once per growing season typically decline in vigor and abundance (Holscher 1945, Whitman and Helgeson 1946, Buwai and Trlica 1977). Early August defoliation, plus a second defoliation applied in midSeptember, for 3 consecutive years reduced yields and standing dead phytomass of a northern wheatgrass-(Agropyron dasystachyum [Hook.] Scribn., syn. Elymus lanceolatus [Scrib. \& Smith] Gould) dominated community (Zhang and Romo 1994). Clipping once per year reduced density of western wheatgrass (Agropyron smithii Rybd., syn. Pascopyrum smithii [Rydb.] Löve), and density and yield of needle-and-thread (Stipa comata Trin. \& Rupr.) (Whitman and Helgeson 1946). Thus, with only 1 or 2 defoliations per growing season, productivity of mixed prairie can be impaired.

Northern wheatgrass, a perennial, cool season, rhizomatous species, common on loam to clay soils (Coupland 1950) decreases with over-grazing on Northern Mixed Prairie (Abouguendia 1990). We hypothesized that this reduction may be related to slow regrowth and the need for a prolonged rest period to regain production potential following grazing. The objective of this research was to determine the length of rest required for green and dead phytomass and above-ground net primary production of northern wheatgrass to return to levels of an unmowed control following a single mowing event on several different dates during the growing season.

\section{Materials and Methods}

\section{Site Description}

The study site was located on the University of Saskatchewan, Matador Research Station, about $70 \mathrm{~km}$ north of Swift Current, Saskatchewan $\left(50^{\circ} 42^{\prime} \mathrm{N}, 107^{\circ} 43^{\circ} \mathrm{W}\right.$, elevation $\left.685 \mathrm{~m}\right)$. Soils are heavy clay belonging to the Rego Brown and Calcareous Brown subgroups in the Sceptre association of the Chernozemic Order (Aridic Borolls) (Coupland et al. 1974). Temperatures of the 
region average $3.3^{\circ} \mathrm{C}$ and range from a monthly mean of $-14.5^{\circ} \mathrm{C}$ in January to $18.8^{\circ} \mathrm{C}$ in July (Environment Canada 1992). Annual precipitation averages $327 \mathrm{~mm}$ with about $60 \%$ of the total received from May through August.

Vegetation of this site belongs to the Agropyron-Koeleria faciation of the Northern Mixed Prairie with northern wheatgrass and western wheatgrass producing about $75 \%$ of the phytomass (Coupland et al. 1974), 80 to $85 \%$ of which is produced by northern wheatgrass (Coupland 1950). Other common graminoids include Junegrass (Koeleria cristata Pers.), green needlegrass (Stipa viridula Trin.), and low sedge (Carex eleocharis Bailey). Fringed sagebrush (Artemisia frigida Willd.) is a common suffrutescent dicot while winterfat (Eurotia lanata [Pursh] Moq.) is an abundant shrub. This range, protected from grazing for over 25 years, is in excellent condition.

\section{Environmental Data}

Precipitation records were obtained from Beechy, Saskatchewan, $40 \mathrm{~km}$ northeast of the study site. Precipitation received from April through August was 199, 104, 131, and 87\% of normal from 1991 through 1994, respectively (Table 1). A Campbell $21 \mathrm{X}$ datalogger recorded daily maximum and minimum air temperatures throughout the study at the research station. Using a base temperature of $0^{\circ} \mathrm{C}$, degree-days were calculated (Eq. 1) (Frank and Hofmann 1989):

Degree-days $=\Sigma$ (daily maximum temp. + daily minimum temp.) $/ 2$ (1)

Accumulation of degree-days began the first day after 1 March on which the average daily air temperature exceeded $0^{\circ} \mathrm{C}$ for 5 consecutive days. Degree-day accumulation was stopped on the first of 5 consecutive days in October in which the average daily air temperature was less than $0^{\circ} \mathrm{C}$. Accumulated degree-days from March through October were 2,762, 2,622, and 2,565 in 1991, 1992, and 1993, respectively (Table 2). Temperatures were not recorded in September and October 1994, but the accumulated degree-days from March through August were similar to the 3 preceding years.

Table 1. Precipitation received near the study site at Beechy, Saskatchewan during the study period.

\begin{tabular}{|c|c|c|c|c|c|c|c|c|}
\hline \multirow[b]{2}{*}{ Year } & \multicolumn{7}{|c|}{ Month } & \multirow[b]{2}{*}{ Total } \\
\hline & Oct.-Mar & Apr. & May & Jun. & Jul. & Aug. & Sep. & \\
\hline & -- & $\because$ & . & $\cdots(n$ & & & & \\
\hline $1990-91$ & 67 & 59 & 65 & 224 & 40 & 36 & 12 & 503 \\
\hline $1991-92$ & 82 & 8 & 48 & 33 & 80 & 52 & 41 & 344 \\
\hline $1992-93$ & 104 & 20 & 15 & 50 & 69 & 124 & 28 & 410 \\
\hline 1993-94 & 109 & 8 & 63 & 65 & 9 & 40 & 19 & 313 \\
\hline \multicolumn{9}{|l|}{ Mean } \\
\hline $1961-90$ & 85 & 16 & 40 & 63 & 60 & 34 & 30 & 327 \\
\hline
\end{tabular}

\section{Experimental Design and Mowing Treatments}

In 1991 and 1992, 9 mowing treatments involving different dates of mowing and an unmowed control were replicated 10 times in a randomized-complete-block design (Petersen 1985). Separate blocks were used for each year and treatments were randomized within replicates of each. Mowing treatments were imposed from early May to late August at about 2-week intervals.
Table 2. Degree-days (DD) accumulated at the Matador Research Station in 1991, 1992, 1993, and 1994. Base temperature $=0^{\circ} \mathrm{C}$.

\begin{tabular}{|c|c|c|c|c|c|c|c|c|}
\hline \multirow[b]{2}{*}{ Year } & \multicolumn{8}{|c|}{ Month } \\
\hline & Mar. & Apr. & May & Jun. & Jul. & Aug. & Sep. & Oct. \\
\hline & -- & & &.- & D) - - & - & . & $\ldots$ \\
\hline 1991 & 22 & 233 & 578 & 1,069 & 1,662 & 2,312 & 2,709 & 2,762 \\
\hline 1992 & 91 & 246 & 600 & 1,084 & 1,596 & 2,116 & 2,456 & 2,622 \\
\hline 1993 & 52 & 238 & 622 & 1,072 & 1,572 & 2,092 & 2,411 & 2,565 \\
\hline 1994 & 23 & 210 & 597 & 1,067 & 1,667 & 2,276 & $\ldots 1$ & -..- \\
\hline Mean & 47 & 232 & 599 & 1,073 & 1,624 & 2,199 & 2,525 & $2,650^{2}$ \\
\hline
\end{tabular}

Temperatures were not recoriled in September and October 1994.

${ }^{2}$ Means for September and October are based on degree-days for 1991 through 1993.

Five by $10-\mathrm{m}$ plots were mowed to a $5-\mathrm{cm}$ stubble with a sickle mower and mowed material was raked and removed. Thus, standing dead and green were removed, but litter was not. Plots were mowed only once.

\section{Phytomass Dynamics}

The amount of phytomass removed from northern wheatgrass by mowing was determined by clipping the residual stubble at ground level within a $0.25 \mathrm{~m}^{2}$ quadrat in each replicate immediately after mowing, and subtracting this phytomass from the phytomass clipped from $0.25 \mathrm{~m}^{2}$ quadrats in the control. Phytomass for species other than northern wheatgrass in the sward ranged from 32 to $46 \%$ of the total (Kowalenko 1995). The amount of nitrogen $(\mathrm{N})$ removed with green phytomass in northern wheatgrass was estimated using mean monthly $\mathrm{N}$ concentrations determined for northern wheatgrass (Li 1990). (Eq. 2):

$\mathrm{N}$ removed $\left(\mathrm{g} \mathrm{m}^{2}\right)=$ [green phytomass removed $\left.\left(\mathrm{g} \mathrm{m}^{-2}\right)\right] \mathrm{X}\left[\mathrm{g} \mathrm{g}^{-1} \mathrm{~N}\right.$ in foliage] (2)

Regrowth of northern wheatgrass was estimated by clipping, to ground level one, $0.25 \mathrm{~m}^{2}$ quadrat per replicate at about 2-week intervals throughout the growing season for 2 to 3 years after mowing. In control plots, standing dead and litter produced previous years were removed from the quadrat before clipping. All samples were oven-dried for at least 48 hours at $80^{\circ} \mathrm{C}$, separated into green and dead material, and weighed. Dead phytomass produced in the current year consisted of the attached, dead leaf blades, and sheaths that were yellow, brown, or gray (Coupland and Abouguendia 1974).

\section{Above-ground Net Primary Production}

Above-ground net primary production of northern wheatgrass, in 2 or 3 years following mowing in 1991 or 1992, was calculated using trough-peak analysis (Redmann 1991). Cumulative aboveground net primary production during May through August was estimated by adding all coinciding positive increments in live and dead phytomass of each mowing treatment.

\section{Etiolated Growth}

Etiolated growth of northern wheatgrass mowed in 1991 or 1992 was determined by placing metal cans $15.6 \mathrm{~cm}$ in diameter and $25 \mathrm{~cm}$ tall in the center of each plot. The tin-coated cans were placed about $10 \mathrm{~cm}$ into the soil during March of the year following mowing. Growth under the cans was harvested at ground level on 20 May 1992 and 6 May 1993 for treatment years 1991 and 1992, respectively. Samples were oven-dried at $80^{\circ} \mathrm{C}$ for 48 hours and weighed. 


\section{Data Analysis}

All data of green and dead phytomass and above-ground net primary production were analyzed separately for each sampling date and year of treatment with analysis of variance in a randomized-complete-block design (Petersen 1985). Green and dead phytomass and above-ground net primary production of northern wheatgrass were considered to have recovered from the mowing treatment when they were not significantly different $(P \geq 0.05)$ from the unmowed control on at least 2 consecutive sampling dates. Where significant differences existed among treatments, means were compared to the control using Least Significant Difference (Petersen 1985). Degree-days accumulated since mowing were then determined for each treatment. Regression analysis (Snedecor and Cochran 1980) was used to determine the best fit $(\mathrm{P} \leq 0.05)$ regression equation to describe relationships between the number of days past 1 May that plants were mowed and the accumulated degree-days for phytomass and aboveground net primary production in each treatment to equal that of the control. The 1 May date was chosen as a reference because it represents the start of grazing in this region. Statistical significance in all tests was $P \leq 0.05$.

\section{Results}

\section{Phytomass and Nitrogen Removal}

Green phytomass removed by the mowing treatments (Table 3) ranged from $3 \%$ of the potential above-ground net primary production in 1991 to 35\% in 1992. In 1991 green phytomass was greatest in mid- to late July and least in May and early June, whereas in 1992 it was greatest in mid-June to mid-July. Standing dead phytomass was greatest in July and August 1991, and early May to mid-July 1992 (Table 3).

Table 3. Quantity of phytomass removed and the estimated amount of nitrogen removed from green phytomass for northern wheatgrass mowed in 1991 and 1992.

\begin{tabular}{|c|c|c|c|}
\hline \multirow{2}{*}{$\begin{array}{l}\text { Date of } \\
\text { Mowing }\end{array}$} & \multicolumn{2}{|c|}{ Phytomass } & \multirow[b]{2}{*}{ Nitrogen } \\
\hline & Live & Dead & \\
\hline 1991 & $\ldots$ & $-\left(\mathrm{g} \mathrm{m}^{-2}\right) \ldots$ & $\ldots \ldots$ \\
\hline 6 May & 6.3 & -1 & 0.13 \\
\hline 21 May & 10.9 & - & 0.23 \\
\hline 4 Jun. & 12.6 & 18.0 & 0.20 \\
\hline 17 Jun. & 37.8 & 26.2 & 0.60 \\
\hline $4 \mathrm{Jul}$. & 38.5 & 35.4 & 0.46 \\
\hline $16 \mathrm{Jul}$. & 57.9 & 53.4 & 0.69 \\
\hline $30 \mathrm{Jul}$. & 61.3 & 45.1 & 0.74 \\
\hline 12 Aug. & 39.7 & 43.5 & 0.44 \\
\hline 27 Aug. & 40.3 & 47.9 & 0.44 \\
\hline \multicolumn{4}{|l|}{1992} \\
\hline 10 May & 11.6 & 78.7 & 0.24 \\
\hline 19 May & 11.1 & 95.3 & 0.23 \\
\hline 2 Jun. & 17.3 & 109.2 & 0.28 \\
\hline 19 Jun. & 30.9 & 77.8 & 0.49 \\
\hline 29 Jun. & 32.2 & 98.4 & 0.52 \\
\hline $17 \mathrm{Jul}$. & 31.6 & 108.8 & 0.38 \\
\hline 27 Jul. & 25.0 & 32.5 & 0.30 \\
\hline 11 Aug. & 16.7 & 13.5 & 0.18 \\
\hline 25 Aug. & 10.0 & 8.5 & 0.11 \\
\hline
\end{tabular}

${ }^{1}$ Amount of dead phytomass removed was not determined in May 1991.

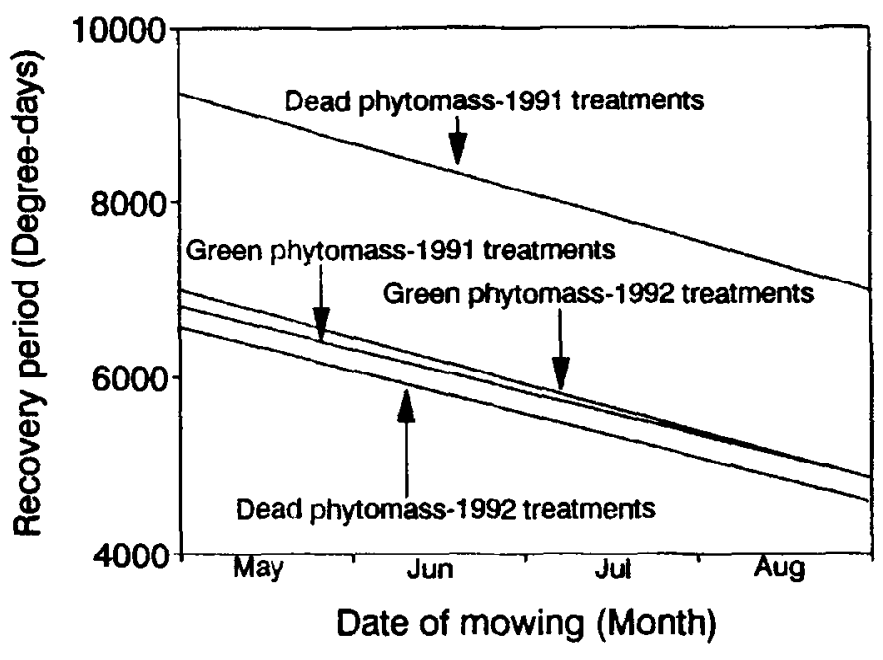

Fig. 1. Regression lines for relationships between the cumulative degree-days required for standing crops of green and dead phytomass to recover to control levels for northern wheatgrass mowed in 1991 or 1992. Regression equations are $Y=6,761-15.7 X, r^{2}=$ $0.91(P<0.001)$ for green and $Y=9,146-17.6 X, r^{2}=0.81(P=$ 0.002 ) for dead phytomass in 1991. Regression equations are $Y=$ $6,963-17.7 X, r^{2}=0.64(P=0.021)$ for green and $Y=6,511-15.8 X$, $r^{2}=0.99(P<0.001)$ for dead phytomass in 1992, respectively. Degree-days were calculated using a base temperature of $0^{\circ} \mathrm{C}$, and $X$ is the number of days past 1 May that plants were mowed.

In 1991 the mass of nitrogen was greatest in mid-June and midto late July, and least in May and early June (Table 3). Maximum amounts of nitrogen were removed from mid-June to mid-July in 1992 when plants were at the peak of their seasonal growth.

\section{Phytomass Recovery}

Rate of recovery of green and dead phytomass for northern wheatgrass was affected by date of mowing and year of treatment. Degree-days needed for replacing green and dead phytomass declined linearly, and were highly correlated with the number of days past 1 May that plots were mowed (Fig. 1). Regardless of time of mowing, green phytomass of northern wheatgrass never equaled the control again in the year of treatment. High coefficients of determination in both years suggests that within years of treatment, date of mowing affected regrowth of northern wheatgrass more than environmental factors.

For each day that mowing was delayed after 1 May, recovery of green phytomass in mowed plots to control levels required 15.7 fewer degree-days in 1991 and 17.7 in 1992 (Fig. 1). Green phytomass increased each year in mowed plots and equaled control levels by August of the second full growing season. Recovery of standing dead phytomass required 17.6 fewer degree-days in 1991 and 15.8 in 1992 for each day mowing was delayed after 1 May (Fig. 1). Dead phytomass increased in mowed plots to control levels by July of the second full growing season in 1991 and the third in 1992.

\section{Above-ground Net Primary Production}

Above-ground net primary production recovered more quickly in both years as date of mowing was delayed, with more degreedays needed in 1991 than 1992 (Fig. 2). The higher intercept and the less steep slope of the regression equation in the 1991 plots 


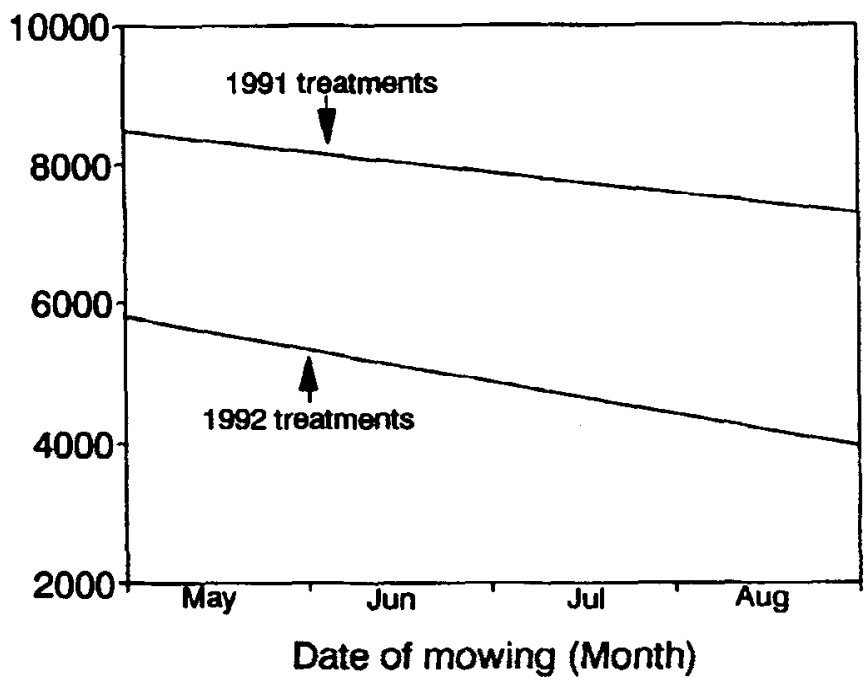

Fig. 2 Regression lines for relationships between the degree-days needed for above-ground net primary production (ANPP) to recover to control levels for northern wheatgrass mowed in 1991 or 1992. Regression equations are $Y=8,515-10.1 X, r^{2}=0.99(P=$ $0.001)$ in 1991 and $\left.Y=5,801-15.1 X, r^{2}=0.67\right)(P=0.007)$ in 1992. Degree-days were calculated using a base temperature of $0^{\circ} \mathrm{C}$, and $\mathrm{X}$ is the number of days past 1 May that plants were mowed.

than those treated in 1992 indicates that effects of mowing were more severe in a wet year than in one with near normal precipitation (Table 1).

Degree-days needed for above-ground net primary production of mowed plots to equal the control level were accumulated by June of the second and third growing seasons for the 1991 and 1992 treatment years, respectively. In the 1991 plots, aboveground net primary production in control was 1.4 to 2.6 times greater than in mowed plots in 1992, 1.4 to 1.7 times greater in 1993, and was similar among treatments in 1994 (Table 4).

In the 1992 plots, above-ground net primary production in the control was 1.3 to 1.6 times greater than in mowed plots (Table 4). Production by northern wheatgrass was similar among treatments in 1994, the second full growing season after mowing.

\section{Etiolated Growth}

Etiolated growth in spring 1992 was reduced $(P \leq 0.05)$ by mowing in early or late July 1991 compared to the control (Table 5). A trend of less etiolated growth was evident in plants defoliated in mid-July and late August. Etiolated growth was not affected by mowing in 1992 ( $P>0.05)$, averaging $16.1 \mathrm{~g} \mathrm{~m}^{-2}(\mathrm{SE}=2.5)$.

\section{Discussion}

Northern wheatgrass was extremely responsive to date of mowing during the growing season. Regardless of the time of herbage removal, more than 2 growing seasons were needed for recovery of above-ground net primary production and standing crops of green and dead phytomass; shorter recovery periods were required as mowing was delayed from early May to late August. Campbell (1952) also reported that grazing of Northern Mixed Prairie early in the growing season reduced production, and
Table 4. Above-ground net primary production of northern wheatgrass mowed in 1991 or 1992 and determined the following 2 or 3 years.

\begin{tabular}{|c|c|c|c|}
\hline \multirow[b]{2}{*}{$\begin{array}{l}\text { Date of } \\
\text { mowing }\end{array}$} & \multicolumn{3}{|c|}{ Year of determination } \\
\hline & 1992 & 1993 & 1994 \\
\hline & \multicolumn{3}{|c|}{$\ldots \ldots \ldots-\ldots\left(\mathrm{g} \mathrm{m}^{-2}\right)-\ldots \ldots$} \\
\hline \multicolumn{4}{|c|}{ 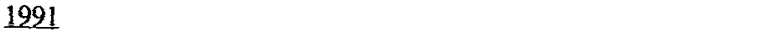 } \\
\hline Control & 176 & 156 & 168 \\
\hline 6 May & 129 & $144^{1}$ & 152 \\
\hline 21 May & 103 & 114 & 175 \\
\hline 4 Jun. & 124 & $\underline{129}$ & $\underline{178}$ \\
\hline 17 Jun. & 98 & 97 & $\underline{179}$ \\
\hline $4 \mathrm{Jul}$. & 89 & 97 & 178 \\
\hline $16 \mathrm{JuI}$ & 75 & 97 & 138 \\
\hline $30 \mathrm{Jul}$. & 67 & 97 & $\underline{162}$ \\
\hline 12 Aug. & 79 & 111 & $\underline{165}$ \\
\hline 27 Aug. & 70 & 93 & 144 \\
\hline SE & 16 & 19 & 24 \\
\hline \multicolumn{4}{|l|}{1992} \\
\hline Control & --- & 156 & 198 \\
\hline 10 May & $\cdots$ & 119 & $\underline{150}$ \\
\hline 19 May & --- & 119 & $\underline{174}$ \\
\hline 2 Jun. & --- & 124 & 177 \\
\hline 19 Jun. & $\cdots$ & 100 & $\underline{162}$ \\
\hline 29 Jun. & $-\cdots$ & 106 & $\underline{170}$ \\
\hline $17 \mathrm{Jul}$ & --- & 108 & 147 \\
\hline 27 Jul. & $\ldots$ & 105 & $\underline{184}$ \\
\hline 11 Aug. & $\cdots$ & 106 & $\underline{146}$ \\
\hline 25 Aug. & -- & 95 & $\underline{174}$ \\
\hline SE & $\cdots$ & 12 & 27 \\
\hline
\end{tabular}

Underlined values within a year of determination and year of mowing are not significantly $(\mathbf{P}>0.05)$ different from control.

Zhang and Romo (1994) recommended deferring grazing to allow maximum forage yield.

Interrupting growth of northern wheatgrass by defoliation any time during the growing season disrupts the production potential that year and the following ones. Reduced production does not appear closely related to the amount of leaf area removed because there are about 2.5 green leaves on each culmless tiller of northern wheatgrass throughout the growing season (Coupland and Abouguendia 1974, Li 1990). The physiological importance of these leaves, however, varies considerably over the growing season. Net photosynthesis of northern wheatgrass peaks in early June, and steadily declines the remainder of the growing season (Redmann 1978a). When defoliated, northern wheatgrass loses virtually all of its photosynthetic capacity. This forgone photosynthetic potential probably creates a carbon deficit in plants (Caldwell 1984), reducing leaf production, axillary bud development, and root growth ( $\mathrm{Li}$ and Redmann 1992a, Zhang and Romo 1994). When the carbon budget over the growing season is considered, delaying defoliation presumably reduces the carbon deficit compared to herbage removal on earlier dates, enabling quicker recovery of phytomass. Therefore, within a growing sea-

Table 5. Etiolated growth in the spring of 1992 for northern wheatgrass plants mowed in 1991.

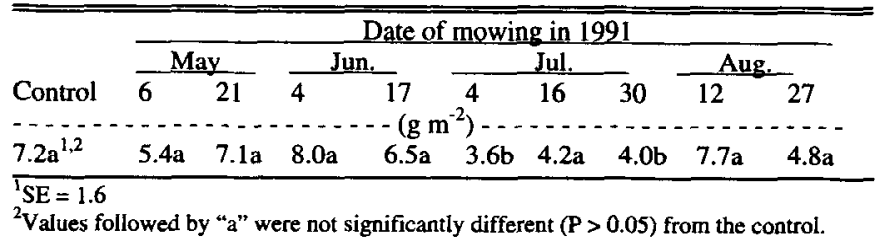


son it is important to allow ample opportunity for photosynthesis before grazing and to maintain residual leaf area for recovery after herbage removal. This proposal is consistent with the suggestion that use of rangeland dominated by northern wheatgrass should be delayed at least until late July to allow maximum growth (Zhang and Romo 1995).

The time required for above-ground phytomass to recover in northern wheatgrass after herbage removal was similar to, or less than that of bluebunch wheatgrass (Agropyron spicatum [Pursh] Scribn. \& Smith, syn. Elytrigia spicata [Pursh] D.R. Dewey) and Idaho fescue (Festuca idahoensis Elmer.) (Mueggler 1975), and blue grama (Bouteloua gracilis [HBK.] Lag.) (Trlica et al. 1977); but more than that of smooth brome (Bromus inermis Leyss.) (Harrison and Romo 1994) and crested wheatgrass (Agropyron cristatum [L.] Gaertn.) (Harrison 1993). As in the present study, Zhang (1992) predicted that 2 to 3 years of rest is needed for above-ground yield components to recover following grazing on Northern Mixed Prairie. Slow recovery of northern wheatgrass from defoliation can be explained by several intrinsic and extrinsic factors.

Concomitant with a reduction of leaf area and attendant photosynthesis, 25 to $45 \%$ of the nitrogen taken up annually by northern wheatgrass ( $\mathrm{Li}$ and Redmann 1992b) was removed by mowing. Northern wheatgrass translocates most of the nitrogen from aging shoots into growing tissues ( $\mathrm{Li}$ and Redmann 1992b). Defoliation undoubtedly disrupts this balance and the nitrogen pool must be replenished, necessitating that plants make many physiological adjustments to regain full growth potential. Plants defoliated in 1991 had a larger peak in green phytomass than those defoliated in 1992, and consequently lost more nitrogen and needed a longer recovery.

Busso et al. (1990) suggested that energy reserves may be reduced when moisture conditions are favorable because plants may divert more energy to luxuriant growth and less to storage, thereby affecting their vigor. This notion is supported by the fact that etiolated growth, an estimate of the ability of plants to mobilize stored energy reserves and produce new shoot tissue without photosynthesizing (Richards and Caldwell 1985), of northern wheatgrass was reduced by some of the 1991 treatments but not by those in 1992. Greater primary production in 1991 was associated with a longer rest period required for recovery of phytomass following defoliation. Therefore, it does not appear advisable to increase stocking rates to take advantage of extra forage production in wet years. This extra foliage should be left as carry-over to enable the plants to replenish their energy reserves, maintain vigor, and allow for accumulation of dead material.

Resting northern wheatgrass-dominated range until green and dead phytomass have recovered to levels equal to ungrazed conditions is also critical for reducing environmental extremes. Presence of dead phytomass reduces evaporation, increases water infiltration, and improves water relations in Northern Mixed Prairie (Redmann 1978b, Willms et al. 1993). Dead phytomass also moderates the temperature regime within the plant microclimate (Whitman 1974, Romo, unpub. data). Taken together these factors promote photosynthesis, and maximum productivity of Northern Mixed Prairie is achieved with maximum litter quantity (Willms et al. 1986, 1993).

\section{Management Implications}

Northern wheatgrass is one of the most sensitive species to over-grazing in Northern Mixed Prairie. Although spring or early summer use of Northern Mixed Prairie is possible, maximum forage yield and stand survival for northern wheatgrass can be obtained if grazing is deferred (Zhang and Romo 1994, 1995). Recovery of above-ground net primary production and standing crop will be quicker with deferment of grazing. Romo et al. (1995) also recommended that grazing systems with more than 1 grazing period each year, or those with prolonged grazing periods should be avoided on native range in the Northern Mixed Prairie to prevent grazing of regrowth and weakening of plants. Based on the findings of this study we conclude that grazing systems on northern wheatgrass-dominated rangeland should include a 2year rest period applied to paddocks after grazing. This rest will allow plants to recover above-ground net primary production and standing crop.

\section{Literature Cited}

Abouguendia, Z.M. 1990. A Practical Guide to Planning for Management and Improvement of Saskatchewan Rangeland: New Pasture Grazing Tech. Proj. Regina. Sask.

Anderson, J.E. and K.E. Holte. 1981. Vegetational development over 25 years without grazing on sagebrush-dominated rangeland in southeastern Idaho. J. Range Manage. 34:25-29.

Busso, C.A., J.H. Richards, and N.J. Chatterton. 1990. Nonstructural carbohydrates and spring regrowth of two cool-season grasses: Interaction of drought and clipping. J. Range Manage. 43:336-343.

Buwai, M. and M.J. Trlica. 1977. Multiple defoliation effects on herbage yield, vigor, and total nonstructural carbohydrates of five range species. J. Range Manage. 30:164-171.

Caldwell, M.M. 1984. Plant requirements for prudent grazing, p. 117-152. In: Developing strategies for rangeland management. Nat. Res. Coun./Nat. Acad. of Sci. Westview Press, Boulder, Colo.

Campbell, J.B. 1952. Farming range pastures. J. Range Manage. 5:252-258.

Coupland, R.T. 1950. Ecology of mixed prairie in Canada. Ecol. Monogr. 20:271-315.

Coupland, R.T., J.R. Willard, and E.A. Ripley. 1974. Summary of activities, 1967-1974. Matador Proj. Tech. Rep. No. 69. Univ. Sask., Saskatoon, Sask..

Coupland, R.T. and Z. Abouguendia. 1974. Producers: V. Dynamics of shoot development in grasses and sedges. Matador Proj. Tech. Rep. No. 51. Univ. Sask., Saskatoon, Sask.

Environment Canada, Atmospheric Environment Service. 1992. Canadian climate normals (1961-1990), temperature and precipitation (Prairie provinces). Environment Canada, Ottawa, Ontario.

Frank, A.B. and L. Hofmann. 1989. Relationship among grazing management, growing degree-days, and morphological development for native grasses on the Northern Great Plains. J. Range Manage. 42:199-202.

Harrison, $T$. 1993. Time requirements for rest following defoliation in crested wheatgrass, p. 159-168. In: F.K. Taha, Z. Abouguendia, and P.R. Horton (eds.), Proc. First Interprov. Range Conf. Grazing and Pasture Techn. Program. Regina, Sask.

Harrison, T. and J.T. Romo. 1994. Regrowth of smooth bromegrass (Bromus inermis Leyss.) following defoliation. Can. J. Plant Sci. 74:531-537.

Holscher, C.E. 1945. The effects of clipping bluestem wheatgrass and blue grama at different heights and frequencies. Ecol. 26:148-156. 
Kowalenko, B.L. 1995. Rest requirements and cold hardiness of northem wheatgrass (Agropyron dasystachyum (Hook.) Scribn.) following defoliation. M.Sc. Thesis. Univ. of Saskatchewan, Saskatoon, Sask.

Li, Y. 1990. Nitrogen budget of northern wheatgrass (Agropyron dasystachyum (Hook.) Scribn.). Ph.D. Diss., Univ. of Saskatchewan, Saskatoon, Sask.

Li, Y.S. and R.E. Redmann. 1992a. Growth responses to ammonium-N, nitrate-N, and defoliation in Agropyron dasystachyum from the Canadian mixed grassland. Amer. Midl. Natur. 127:300-308.

Li, Y.S. and R.E. Redmann. 1992b. Nitrogen budget of Agropyron dasystachyum in Canadian mixed prairie. Amer. Midl. Natur. 128:61-71.

Mueggler, W.F. 1975. Rate and pattern of vigor recovery in Idaho fescue and bluebunch wheatgrass. J. Range Manage. 28:198-204.

Petersen, R.G. 1985. Design and analysis of experiments. Marcel Dekker, New York.

Redmann, R.E. 1978a. Seasonal dynamics of carbon dioxide exchange in a mixed grassland ecosystem. Can. J. Bot. 56:1999-2005.

Redmann, R.E. 1978b. Plant and soil water potentials following fire in northern mixed grassland. J. Range Manage. 31:433-445.

Redmann, R.E. 1991. Primary productivity, p. 75-93. In: Coupland R.T. (ed.) Natural grasslands - Introduction and western hemisphere. Ecosystems of the world. 8A. Elsevier, N.Y.

Richards, J.H. and M.M. Caldwell. 1985. Soluble carbohydrates, concurrent photosynthesis, and efficiency in regrowth following defoliation: A field study with Agropyron species. J. Appl. Ecol. 22:907-920.

Romo, J.T., R.E. Redmann, B.L. Kowalenko, and A.R. Nicholson. 1995. Growth of winterfat following defoliation in Northern Mixed Prairie of Saskatchewan. J. Range Manage. 48:240-245.
Snedecor, G.W. and W.C. Cochran. 1980. Statistical methods. Iowa State Univ. Press, Ames, Iowa.

Trlica, M.J., M. Buwai, and J.W. Menke. 1977. Effects of rest following defoliations on the recovery of several range species. J. Range Manage. 30:21-27.

Voisin, A. 1959. Grass productivity. Reprinted in 1988, Island Press Edition, Covelow, Calif.

Whitman, W.C. 1974. Influence of grazing on the microclimate of mixed grass prairie, p. 207-218. In: K.W. Kreitlow and R.H. Hart (coordinators), Plant morphogenesis as the basis for scientific management of range resources. U.S.D.A. Misc. Pub. 1271.

Whitman, W.C. and E.A. Helgeson. 1946. Range vegetation studies. N. Dak. Agr. Exp. Sta. Bull. 340.

Willms, W.D., S. Smoliak, and A.W. Bailey. 1986. Herbage production following litter removal on Alberta native grasslands. J. Range Manage. 39:536-540.

Willms, W.D., S.M. McGinn, and J.F. Dormaar. 1993. Influence of litter on herbage production in the mixed prairie. J. Range Manage. 46:320-324.

Zhang, J. 1992. Vegetation responses to rest and multiple clipping regimes in an Agropyron dasytachyum dominated grassland. Ph.D. Diss., Univ. of Saskatchewan, Saskatoon, Sask.

Zhang, J. and J.T. Romo. 1994. Defoliation of a northern wheatgrass community: Above- and below-ground phytomass productivity. J. Range Manage. 47:279-284.

Zhang, J. and J.T. Romo. 1995. Impacts of defoliation on tiller production and survival in northern wheatgrass. J. Range Manage. 48:115-120. 